STUDIA I PRACE WYDZIAŁU NAUK EKONOMICZNYCH I ZARZĄDZANIA nr 41, t. 2

\author{
Agnieszka Kłysik-Uryszek* \\ Anetta Kuna-Marszałek** \\ Uniwersytet Łódzki
}

\title{
DOŚWIADCZENIA PROCESU INTERNACJONALIZACJI PRZEDSIĘBIORSTW REGIONU ŁÓDZKIEGO. PRÓBA WERYFIKACJI MODELU UPPSALSKIEGO ${ }^{1}$
}

\begin{abstract}
Streszczenie
Pierwsze dziesięciolecie uczestnictwa Polski w UE istotnie zwiększyło zainteresowanie rodzimych przedsiębiorstw podejmowaniem bezpośrednich inwestycji zagranicznych, choć w poszczególnych województwach nie było ono równomierne. To nasuwa pytanie o motywy i cele podejmowanych inwestycji, a także o wybierane ścieżki ekspansji. Celem artykułu jest prezentacja procesu internacjonalizacji przedsiębiorstw z województwa łódzkiego w kontekście założeń uppsalskiego modelu umiędzynarodowienia. Wyniki badań potwierdzają tezę, że przedsiębiorstwa z województwa łódzkiego, podobnie jak przeciętnie wszystkie polskie przedsiębiorstwa (z wyłączeniem firm sektora finansowego), dokonują ekspansji zgodnej z fazowym modelem uppsalskim. Ze względu na relatywnie niewielkie doświadczenie w procesach aktywnego umiędzynarodowienia dominują jak dotąd takie formy bezpośredniej obecności na rynkach zagranicznych, które powalają zwiększyć sprzedaż, czyli de facto wspierają eksport. Najpopularniejszymi kierunkami ekspansji są rynki krajów ościennych, o niewielkim dystansie psychicznym.
\end{abstract}

Słowa kluczowe: model uppsalski, bezpośrednie inwestycje polskich przedsiębiorstw

* E-mail: aklysik@uni.lodz.pl

** E-mail: akuna@uni.lodz.pl

1 Badanie przeprowadzono w ramach projektu „Determinanty i efekty aktywnej internacjonalizacji przedsiębiorstw z województwa łódzkiego" finansowanego przez Narodowe Centrum Nauki (UMO-2011/01/B/ HS4/03372). 


\section{Wprowadzenie}

Intensywne zmiany gospodarcze zachodzące w gospodarce światowej w ostatnich latach, globalizacja oraz zaawansowane procesy integracyjne sprawiły, że przedsiębiorstwa coraz chętniej poszukują atrakcyjnych warunków prowadzenia działalności także poza granicami kraju macierzystego.

Celem artykułu jest prezentacja procesu internacjonalizacji przedsiębiorstw z województwa łódzkiego w kontekście założeń uppsalskiego modelu umiędzynarodowienia. Na podstawie danych statystycznych GUS podjęto próbę weryfikacji modelu w odniesieniu do kierunków geograficznej ekspansji przedsiębiorstw oraz celu ich inwestycji. Artykuł składa się z dwóch części. W pierwszej omówiono teoretyczne ramy internacjonalizacji na podstawie modelu uppsalskiego, w drugiej zaprezentowano wyniki analizy danych opisujących bezpośrednie inwestycje zagraniczne (BIZ) podejmowane przez przedsiębiorstwa $\mathrm{z}$ województwa łódzkiego. Główne wnioski z pracy przedstawiono w podsumowaniu.

\section{Fazowy model internacjonalizacji - ujęcie teoretyczne}

Internacjonalizacja przedsiębiorstw ma związek z postępującymi procesami globalizacji światowej gospodarki, w tym liberalizacją handlu światowego i przepływu kapitału oraz z postępem technologicznym. Jej pojęcie ujmuje się w różnorodny sposób. Najczęściej jest opisywana jako każdy rodzaj działalności gospodarczej podejmowanej przez przedsiębiorstwo za granicą lub jako proces zwiększania zaangażowania międzynarodowego i dostosowywania działań firmy (w zakresie strategii, struktury, zasobów itp.) do specyfiki środowiska międzynarodowego ${ }^{2}$. Choć umiędzynarodowienie może być efektem wykorzystania niespodziewanej okazji lub spontanicznej decyzji, najczęściej wynika z przyjętej strategii i jest efektem zaplanowanych i realizowanych przez firmę działań, które są warunkowane posiadanymi zasobami i atrakcyjnością rynków zagranicznych ${ }^{3}$.

2 J. Johanson, J.E. Vahlne, The internationalization process of the firm - A model of knowledge development and increasing market commitments, „Journal of International Business Studies” 1977, vol. 8(1); J. Johanson, L.-G. Mattsson, Internationalization in industrial systems - a network approach, strategies in global competition, w: The Internationalization of the Firm: A Reader, ed. P.N. Buckley, P.J. Ghauri, Academic Press, London 1993; J. Calof, P.W. Beamish, Adapting to foreign markets: explaining internationalization, „International Business Review” 1995, vol. 4(2).

3 K. Fonfara, M. Łuczak, Przeglad podstawowych modeli internacjonalizacji firmy aspekty behawioralne, w: Zachowanie przedsiębiorstwa w procesie internacjonalizacji. Podejście sieciowe, red. K. Fonfara, PWE, Warszawa 2009, s. 15. 
Rosnące zainteresowanie procesem internacjonalizacji przedsiębiorstw, które pojawiło się na początku lat 60. XX wieku, zaowocowało powstaniem wielu różnych modeli podejmujących próbę wyjaśnienia, w jaki sposób zazwyczaj ono przebiega. Wśród najważniejszych grup teorii można wymienić teorie etapowej internacjonalizacji (np. model uppsalski) ${ }^{4}$, teorie wczesnej internacjonalizacji (modele internacjonalizacji przyspieszonej) $^{5}$ oraz teorie sieciowe ${ }^{6}$. Większość z nich wskazuje na kluczowe determinanty zaangażowania firm w działalność na rynkach trzecich, uzasadnia słuszność podejmowania ekspansji międzynarodowej oraz przedstawia najważniejsze jej skutki. Żadna z tych koncepcji nie ma uniwersalnego zastosowania, a ich aplikacyjność nierzadko jest ograniczona.

Wśród teorii internacjonalizacji model uppsalski jest uznawany za jeden z dominujących ${ }^{7}$, a jego mocną stroną jest uniwersalność i prostota ${ }^{8}$. Wyjaśnia motywy i ścieżki umiędzynarodowienia niezależnie od wielkości firmy oraz sytuacji rynkowej, w jakiej się znajduje. W modelu tym ekspansję przedsiębiorstwa na zagraniczne rynki przedstawia się w kontekście następujących po sobie kolejnych faz (etapów) internacjonalizacji, która jest procesem powolnym i długotrwałym. Zaawansowane umiędzynarodowienie jest konsekwencją wcześniejszego rozwoju i sukcesów na rynku macierzystym, a następnie wchodzenia na rynki krajów najbliższych geograficznie, charakteryzujących się podobną kulturą i poziomem wiedzy. Sekwencyjność procesu internacjonalizacji i wybór rynków zagranicznych są wyjaśniane przez koncepcję tzw. dystansu psychicznego, który wynika m.in. z różnic kulturowych czy warunków do prowadzenia biznesu. Minimalizując wysokie ryzyko związane z prowadzeniem działalności za granicą, firmy najpierw dokonują ekspansji na rynki, które są im ,psychicznie" bliższe, a tym samym charakteryzują się mniejszym prawdopodobieństwem niepowodzenia. Dopiero zdobyte doświadczenie wykorzystują, wchodząc na rynki o większym dystansie psychicznym.

4 J. Johanson, F. Wiedersheim-Paul, The Internationalization of the Firm-Four Swedish Cases, ,,The Journal of Management Studies" 1975, vol. 12(3); J. Johanson, J.E. Vahlne, The internationalization...

5 G.A. Knight, S.T. Cavusgil, The Born Global Firm: A Challenge to Traditional Internationalization Theory, „Advances in International Marketing” 1996, vol. 8; S.T. Cavusgil, G. Knight, Born Global Firms: A New International Enterprise, Business Expert Press, New York 2009.

6 J. Johanson, L.-G. Mattsson, Internationalization in industrial systems...; K. Möller, A. Rajala, Rise of strategic nets - New modes of value creation, „Industrial Marketing Management” 2007, vol. 36; S.I. Ng, M. Zain, The Impacts of Network Relationships on SMEs'Internationalization Process, ,Thunderbird International Business Review" 2006, vol. 48(2).

7 I. Fillis, Small firm internationalisation: an investigative survey and future research directions, „Management Decision" 2001, vol. 39(9).

8 M. Forsgren, The Concept of Learning in the Uppsala internationalization process model: a critical review, „International Business Review” 2002, vol. 11(3). 
Kontrolę nad procesem sprzedaży oraz produkcji przedsiębiorstwo zwiększa stopniowo, przechodząc przez cztery etapy: od sporadycznego eksportu, poprzez eksport realizowany przez niezależnych pośredników, utworzenie filii lub oddziału handlowego aż do produkcji na rynku zagranicznym. $Z$ chwilą gdy firma nabywa doświadczenia i wiedzy, przezwycięża bariery swojego rozwoju i efektywniej działa na innych rynkach.

Jak wspomniano, przedsiębiorstwo rozpoczyna proces umiędzynarodowienia od rynków o najmniejszym dystansie psychicznym. Johanson i Wiedersheim-Paul utożsamiają go z „czynnikami zapobiegającymi lub zakłócającymi przepływ informacji między przedsiębiorstwem a rynkiem"”. Wśród najczęściej występujących można wymienić: różnice językowe, kulturowe, systemy polityczne, systemy edukacji, poziom rozwoju ekonomicznego itd. Przedsiębiorstwa, które zamierzają ominąć wspomniane bariery, inwestują w krajach mających podobny klimat dla prowadzenia biznesu jak kraj macierzysty.

Koncepcja dystansu psychicznego $\mathrm{w}$ procesie internacjonalizacji przedsiębiorstw wielokrotnie była podejmowana $\mathrm{w}$ literaturze przedmiotu. Wielu autorów traktuje dystans psychiczny jako istotny czynnik wyjaśniający wydajność organizacji $1^{10}$ i mający wpływ na proces internacjonalizacji sektora małych i średnich przedsiębiorstw ${ }^{11}$. Kogut i Singh przewidują, że duży dystans psychiczny wzmacnia preferencje firmy do podejmowania inwestycji typu greenfield $^{12}$. Z kolei z badań Brouthers i Brouthers wynika, że zwiększa prawdopodobieństwo dokonania przejęć na rynkach zagranicznych ${ }^{13}$.

Model uppsalski był przedmiotem wielokrotnej krytyki. Kontestowano m.in. jego determinizm i ogólnośćl ${ }^{4}$, adekwatność w odniesieniu do różnych typów produktów i usług ${ }^{15}$ czy brak wyjaśnienia, kiedy i dlaczego firmy pomijają fazy internacjonalizacji już na początkowym etapie, aby przyspieszyć przebieg inter-

9 J. Johanson, F. Wiedersheim-Paul, The Internationalization..., s. 308.

10 J. Evans, F.T. Mavondo, Psychic Distance and Organizational Performance: An Empirical Examination of International Retailing Operations, „Journal of International Business Studies” 2002, vol. 33(3); D. Dikova, Performance of foreign subsidiaries: Does psychic distance matter?, „International Business Review” 2009, vol. 18(1).

11 N. Hashai, T. Almor, Gradually internationalizing 'born global' firms: an oxymoron?, „International Business Review" 2004, vol. 13(4).

12 B. Kogut, H. Singh, The Effect of National Culture on the Choice of Entry Mode, „Journal of International Business Studies" 1988, vol. 19(3).

13 K.D. Brouthers, L.E. Brouthers, Acquisition or greenfield startup? Institutional, cultural and transaction cost influences, „Strategic Management Journal” 2000, vol. 21(1).

14 S. Reid, Firm Internationalization, Transaction Costs And Strategic Choice, „International Marketing Review" 1983, vol. 1(2).

15 S. Bridgewater, The Internationalisation Process and Types of Firms, w: International Business. Theories, Policies and Practices, ed. M. Tayeb, Pearson Education, Harlow 2000. 
nacjonalizacji i szybciej dokonać ekspansji1 ${ }^{16}$. Również koncepcja dystansu psychicznego nie znalazła uznania u wielu badaczy. Model uppsalski zbudowany wokół takiego przekonania staje się dyskusyjny, gdyż nie potrafi w prawidłowy sposób wyjaśnić przebieg procesu internacjonalizacji w warunkach współczesnej gospodarki. Obecnie dystans psychiczny odgrywa coraz mniejszą rolę, ponieważ postęp technologiczny, szybsza komunikacja, przepływ informacji i sprawny transport sprawiają, że rynki stają się coraz bardziej homogeniczne i podobne do siebie ${ }^{17}$.

Pomimo krytyki zarzucającej modelowi uppsalskiemu nieprzydatność w obliczu zmieniającej się sytuacji rynkowej jego założenia mogą znaleźć zastosowanie także w przypadku firm działających współcześnie ${ }^{18}$. Uaktualnione w ostatnich latach wersje modelu uppsalskiego uwzględniają elementy charakterystyczne dla innych teoretycznych podejść, np. widoczne w modelach sieciowych ${ }^{19} \mathrm{czy}$ koncepcjach born global.

\section{Bezpośrednie inwestycje przedsiębiorstw z województwa łódzkiego - weryfikacja modelu uppsalskiego}

Dynamiczne zmiany, jakie zachodziły w Polsce w ostatnim ćwierćwieczu, sprawiły, że polskie przedsiębiorstwa stały się coraz bardziej konkurencyjne nie tylko na rynku krajowym, lecz także na arenie międzynarodowej. Intensywne procesy globalizacji, a także integracja z UE dodatkowo ułatwiły polskim firmom podejmowanie inwestycji bezpośrednich wspierających działalność eksportową, jak również coraz częściej nastawionych na delokalizację produkcji w celu zdobycia rynku, obniżenia kosztów produkcji i poprawy efektywności ${ }^{20}$. Należy jednak podkreślić, że polskie inwestycje zagraniczne są relatywnie nowym fenomenem

16 S. Hollensen, Global Marketing, a decision-oriented approach, Pearson Education Limited, Harlow, Essex 2004.

17 K. Przybylska, Znaczenie dystansu psychicznego w procesie internacjonalizacji polskich przedsiębiorstw, w: Przedsiębiorczość jako niewykorzystane źródło sukcesu polskiej gospodarki, red. E. Okoń-Horodyńska, PTE, Warszawa 2009.

18 M. Forsgren, The Concept...; D.D. Sharma, A. Blomstermo, The internationalization process of born globals: a network view, „International Business Review” 2003, vol. 12(6).

19 J.-E. Vahlne, J. Johanson, New technology, new business environments and new internationalization processes?, w: Critical perspectives on internationalization, ed. V. Havila, M. Forsgren, H. Håkansson, Pergamon, London 2002; J. Johanson, J.E. Vahlne, The Uppsala internationalization process model revisited: From liability of foreignness to liability of outsidership, ,Journal of International Business Studies” 2009, vol. 40(9).

20 Szerzej: A. Kłysik-Uryszek, A. Kuna-Marszałek, Psychic and geographic distance in the process of firm internationalization. Example of companies from Poland and Lodz region, Business and Economic Horizons 2014, vol. 10(1), s. 1-9. 
- ich dynamiczny wzrost można obserwować dopiero po wstąpieniu do UE, przy czym relatywne zainteresowanie podejmowaniem BIZ nie jest jednakowe we wszystkich województwach.

Utrudnieniem badania polskich BIZ w układzie regionalnym jest niestety niewielka dostępność danych statystycznych, szczególnie tych pokazujących skalę i strukturę BIZ na poziomie wojewódzkim ${ }^{21}$. Z tego względu badanie aktywności inwestycyjnej przedsiębiorstw z województwa łódzkiego możliwe było dopiero od 2009 roku, wcześniej dane w takim układzie nie były dostępne.

W badanym okresie 2009-2012 liczba przedsiębiorstw deklarujących posiadanie jednostek zagranicznych wahała się w województwie łódzkim w przedziale 57-70 podmiotów, przy czym najwięcej firm było zaangażowanych w BIZ w 2010 roku. Na tle Polski grupa ta nie jest zbyt duża - stanowi zaledwie około $4,5-5 \%$ wszystkich inwestorów z Polski.

Najliczniejszą grupą wśród inwestorów z województwa łódzkiego były spółki zajmujące się przetwórstwem przemysłowym. Stanowiły one około $48 \%$ wszystkich przedsiębiorstw podejmujących BIZ (jedynie w 2009 roku było ich około $42 \%$ ), co stanowiło około $10-15$ pkt proc. liczniejszą reprezentację niż przeciętnie w całej Polsce. Drugą grupą inwestorów bezpośrednich w województwie łódzkim były firmy zajmujące się handlem (22-26 podmiotów). W pozostałych branżach inwestycje podejmowali pojedynczy przedsiębiorcy (maksymalnie 2-3 podmioty).

W przemyśle dominowali producenci wyrobów z gumy i tworzyw sztucznych (5-7 podmiotów) oraz podmioty reprezentujące przemysł lekki (3-6 producentów wyrobów tekstylnych oraz 2-4 producentów odzieży). Te branże można uznać za trzon specjalizacji inwestycyjnej z województwa łódzkiego, gdyż ich łączny udział w ogólnej liczbie inwestorów przemysłowych przekracza 45\%. W pozostałych gałęziach przemysłu BIZ podejmowali pojedynczy inwestorzy, jedynie wśród producentów wyrobów metalowych oraz urządzeń elektrycznych jednostki zagraniczne miały po około $2-3$ podmioty.

Przeciętnie każdy inwestor posiadał udziały w około dwóch podmiotach powiązanych, jednak należy zwrócić uwagę, że obszar działalności jednostek zagranicznych nie zawsze pokrywał się z obszarem działania spółki matki. Blisko połowa jednostek utworzonych przez spółki przemysłowe zajmowała się wyłącznie handlem (a nie działalnością produkcyjną), czyli de facto wspierała

21 Zasadniczo w polskiej sprawozdawczości dane o BIZ mogą pochodzić ze statystyk bilansu płatniczego (NBP) lub z formularzy sprawozdawczych, do których składania są zobowiązani wszyscy przedsiębiorcy posiadający jednostki zagraniczne (GUS). Tylko to drugie źródło informacji prezentuje dane o inwestorach w interesującym nas układzie regionalnym. 
sprzedaż eksportową spółki matki. Biorąc pod uwagę niewielkie doświadczenie w zakresie aktywnej internacjonalizacji, można stwierdzić, że pokazuje to stopniową, fazową ścieżkę ekspansji - wielu przedsiębiorców decyduje się w pierwszej kolejności na wzmocnienie swojej pozycji na rynkach zagranicznych poprzez dodatkowe wsparcie sprzedaży eksportowej. Dopiero w kolejnych fazach decydują się na delokalizację produkcji.

Zachowawczą strategię ekspansji w pierwszych jej fazach pokazuje również analiza kierunków geograficznych podejmowania BIZ. Inwestorzy z województwa łódzkiego kierowali swoje zagraniczne przedsięwzięcia przede wszystkim do krajów ościennych - ulokowano tam około 60\% jednostek zagranicznych. Najwięcej podmiotów funkcjonowało na Ukrainie, w Rosji i na Litwie. Relatywnie dużym zainteresowaniem cieszył się też rynek Rumunii (tabela 1).

Kierunki inwestycji podmiotów z województwa łódzkiego są zbliżone do tendencji ogólnopolskich, choć przeciętnie dla wszystkich polskich inwestorów najatrakcyjniejszy był rynek niemiecki. Na drugim miejscu znalazła się Ukraina, a następnie Czechy i Rosja. Relatywnie dużo jednostek utworzono na Litwie, Słowacji i w Rumunii, ale także - co nie pokrywa się z inwestycjami przedsiębiorców łódzkich - na Cyprze.

Tabela 1. Liczba jednostek zagranicznych powiązanych z inwestorami zagranicznymi $\mathrm{z}$ województwa łódzkiego w przekroju geograficznym

\begin{tabular}{|l|r|r|r|r|}
\hline \multicolumn{1}{|c|}{ Wyszczególnienie } & 2009 & 2010 & 2011 & 2012 \\
\hline Ogółem & 119 & 137 & 146 & 122 \\
\hline Litwa & 18 & 17 & 20 & 14 \\
\hline Niemcy & 7 & 10 & 11 & 7 \\
\hline Republika Czeska & 9 & 10 & 11 & 10 \\
\hline Rosja & 14 & 18 & 18 & 14 \\
\hline Rumunia & 5 & 10 & 10 & 8 \\
\hline Ukraina & 16 & 17 & 17 & 18 \\
\hline Słowacja & 8 & 9 & 10 & 8 \\
\hline Pozostałe & 42 & 46 & 49 & 43 \\
\hline
\end{tabular}

Źródło: opracowanie własne na podstawie danych GUS.

Litwa dominowała także pod względem wartości osiąganych przychodów przez jednostki powiązane z inwestorami z województwa łódzkiego (tabela 2). $\mathrm{Na}$ drugim miejscu znalazł się rynek rosyjski. Najniższe przychody osiągały podmioty na Ukrainie i w Rumunii, co nie jest zaskakujące, zważywszy na 
chłonność i poziom rozwoju tych rynków, należy bowiem podkreślić, że znakomitą większość produkcji i sprzedaży realizowanej przez jednostki zagraniczne kierowano na rynki krajów goszczących. Zaledwie około 9\% przychodów osiągano z eksportu, przy czym eksport do spółki matki i jednostek powiązanych, który można byłoby traktować jako miernik poziomu pionowej integracji procesu produkcji w firmie, był marginalnie mały.

Tabela 2. Przychody osiągane przez jednostki zagraniczne powiązane $\mathrm{z}$ inwestorami zagranicznymi z województwa łódzkiego

\begin{tabular}{|l|r|r|r|r|r|r|r|r|r|r|r|r|}
\hline \multirow{2}{*}{$\begin{array}{l}\text { Wyszczegól- } \\
\text { nienie }\end{array}$} & \multicolumn{4}{|c|}{ Przychody (mln zł) } & \multicolumn{4}{|c|}{ Udział eksportu w przychodach } & \multicolumn{3}{|c|}{$\begin{array}{c}\text { Udział eksportu pionowego } \\
\text { w przychodach (\%) }\end{array}$} \\
\cline { 2 - 17 } & 2009 & 2009 & 2010 & 2011 & 2012 & 2010 & 2011 & 2012 & 2009 & 2010 & 2011 & 2012 \\
\hline Ogółem & 1095,1 & 245,4 & 369,7 & 407,6 & 4,4 & 7,3 & 8,6 & 9,2 & 1,4 & 3,1 & 2,4 & 4,1 \\
\hline Litwa & 657,8 & 679,5 & 665,2 & 640,2 & 0,0 & 0,0 & 0,1 & 0,2 & 0,0 & 0,0 & 0,0 & 0,2 \\
\hline Niemcy & 91,4 & 124,2 & 271,7 & 115,5 & 0,3 & 24,2 & 91,1 & 47,0 & 0,2 & 0,1 & 0,5 & 0,2 \\
\hline $\begin{array}{l}\text { Republika } \\
\text { Czeska }\end{array}$ & 24,4 & 230,1 & 270,3 & 598,5 & 0,1 & 1,7 & 5,6 & 42,3 & 0,1 & 1,7 & 0,6 & 42,3 \\
\hline Rosja & 75,7 & 225,4 & 491,4 & 767,9 & 0,0 & 0,1 & 0,0 & 0,0 & 0,0 & 0,1 & 0,0 & 0,0 \\
\hline Rumunia & 6,7 & 305,8 & 318,8 & 406,3 & 17,3 & 3,1 & 0,3 & 0,3 & 4,6 & 0,7 & 0,3 & 0,0 \\
\hline Ukraina & 43,6 & 57,1 & 95,0 & 143,2 & 19,5 & 24,4 & 30,9 & 17,0 & 7,6 & 22,0 & 25,5 & 15,5 \\
\hline Słowacja & 11,1 & 1010,7 & 613,8 & 323,8 & 12,4 & 6,1 & 5,1 & 1,0 & 12,4 & 6,1 & 5,1 & 1,0 \\
\hline Pozostałe & 184,4 & 121,2 & 267,8 & 279,3 & 19,9 & 13,9 & 14,1 & 17,4 & 5,7 & 12, & 9,2 & 8,7 \\
\hline
\end{tabular}

Źródło: opracowanie własne na podstawie danych GUS.

Na tym tle na szczególną uwagę zasługują rynki Niemiec i Ukrainy. Pierwszy z nich stanowił platformę eksportu dla znacząco większej części produkcji jednostek zagranicznych firm z województwa łódzkiego (nawet do 91\% w 2011), przy czym sprzedaż ta nie była realizowana z podmiotami powiązanymi. Przedsięwzięcia na rynku niemieckim nie miały zatem charakteru inwestycji pionowych, a były motywowane raczej chęcią wzmocnienia i zwiększenia zasięgu sprzedaży wyrobów firmy. Duże zainteresowanie dobrami wytworzonymi przez polskich inwestorów na rynku niemieckim potwierdza mechanizm efektu kraju pochodzenia. Klienci z krajów chociażby europejskich wyżej cenią dobra wytworzone na wysoko rozwiniętym, konkurencyjnym rynku niemieckim niż polskim. 
Inaczej sytuacja przedstawiała się na Ukrainie. Relatywnie duża sprzedaż eksportowa była kierowana w większości do spółek matek i innych jednostek powiązanych. Można zatem przypuszczać, że część jednostek zagranicznych została zlokalizowana na Ukrainie, aby uzyskać dostęp do tańszych czynników wytwórczych, i stanowi element zintegrowanego pionowo łańcucha tworzenia wartości w przedsiębiorstwach macierzystych. W przeciwieństwie do niemieckich produkty wytworzone na Ukrainie postrzegane są na rynkach międzynarodowych przez pryzmat niskiej konkurencyjności całej gospodarki, stąd niewielki międzynarodowy popyt na nie.

Pomimo niskiej sprzedaży eksportowej ogółem jej udział w wartości przychodów w badanym okresie systematycznie wzrastał. Może to oznaczać, że inwestorzy coraz bardziej świadomie podejmowali BIZ, już nie tylko myśląc o zwiększeniu skali sprzedaży i motywach rynkowych, lecz także o redukcji kosztów wytwarzania dobra na różnych etapach tworzenia łańcucha wartości w firmie (tj. motywach kosztowych i zasobowych).

Podobnie jak w przypadku eksportu także uzależnienie od importu jednostek zagranicznych było zróżnicowane geograficznie ${ }^{22}$. W badanym okresie najmniej (lub prawie wcale) nie importowały jednostki niemieckie (tabela 3). Przy uwzględnieniu proeksportowego nastawienia tych podmiotów nasuwa się pytanie o konkurencyjność komponentów, materiałów i półproduktów pochodzących z Polski. Niewielkie były również zagraniczne zakupy podmiotów litewskich (w relacji do przychodów ich wartość nie przekraczała 3,5\%).

$\mathrm{Z}$ kolei w czołówce rynków, na których jednostki zagraniczne były bardziej uzależnione od importu, znajduje się Rosja, Republika Czeska i Słowacja w latach 2011-2012, a w nieco mniejszym stopniu także Ukraina. W ujęciu wartościowym najwięcej importowały jednostki rosyjskie, jednak w relacji do przychodów stanowiło to tylko około 30-50\%. Duży udział importu w przychodach zanotowano jedynie w spółkach ukraińskich i słowackich (nawet do około 50\% odpowiednio w 2012 i 2011 roku). Warto jednak podkreślić, że pomimo tego zróżnicowania w przeważającej większości krajów import pochodził wyłącznie lub prawie wyłącznie od spółek matek, co świadczy o skali pionowej integracji procesu produkcji wyrobów danego przedsiębiorstwa.

22 Należy oczywiście podkreślić, że informacje statystyczne nie uwzględniają podziału na import zaopatrzeniowy i import inwestycyjny. Wnioski nasuwające się w kontekście relacji wartości importu do przychodów są zatem obarczone błędem - wynikającym z braku możliwości wyodrębnienia wartości importowanych maszyn i urządzeń. 
Tabela 3. Import jednostek zagranicznych powiązanych z inwestorami zagranicznymi z województwa łódzkiego w przekroju geograficznym

\begin{tabular}{|l|r|r|r|r|r|r|r|r|}
\hline \multirow{2}{*}{ Wyszczególnienie } & \multicolumn{6}{|c|}{ Udział importu w przychodach (\%) } & \multicolumn{4}{|c|}{$\begin{array}{c}\text { Udział importu pionowego } \\
\text { n }\end{array}$} \\
\cline { 2 - 10 } & 2009 & 2010 & 2011 & 2012 & 2009 & 2010 & 2011 & 2012 \\
\hline Ogółem & 9,8 & 15,4 & 17,2 & 20,2 & 6,6 & 11,9 & 16,3 & 18,1 \\
\hline Litwa & 0,8 & 1,0 & 3,2 & 2,2 & 0,6 & 1,0 & 3,1 & 2,2 \\
\hline Niemcy & 0,0 & 0,0 & 0,3 & 11,0 & 0,0 & 0,0 & 0,0 & 0,9 \\
\hline Republika Czeska & 33,1 & 66,0 & 26,4 & 31,4 & 32,8 & 65,8 & 26,4 & 31,4 \\
\hline Rosja & 39,9 & 49,1 & 31,7 & 34,1 & 39,9 & 48,4 & 31,7 & 32,6 \\
\hline Rumunia & 85,5 & 11,5 & 16,2 & 36,6 & 66,5 & 11,0 & 15,4 & 34,3 \\
\hline Ukraina & 33,1 & 37,1 & 32,3 & 47,5 & 18,4 & 34,0 & 32,1 & 45,3 \\
\hline Słowacja & 36,0 & 24,4 & 53,0 & 61,1 & 33,6 & 24,3 & 26,9 & 49,4 \\
\hline Pozostałe & 21,2 & 38,0 & 28,2 & 30,8 & 7,2 & 20,2 & 23,9 & 26,4 \\
\hline
\end{tabular}

Źródło: opracowanie własne na podstawie danych GUS.

Z opisanej wyżej struktury eksportu i importu wynika ujemne saldo wymiany handlowej jednostek zagranicznych inwestorów $\mathrm{z}$ województwa łódzkiego, w tym także saldo wymiany pionowej. Najgorszy bilans wymiany można było zaobserwować w jednostkach rosyjskich - ich sytuacja systematycznie pogarszała się z około -30 mln zł w 2009 roku do około -200 mln zł w 2012 roku. Natomiast jedynym krajem, w którym polskie jednostki zagraniczne w całym okresie 2009-2012 utrzymywały dodatnie saldo wymiany handlowej, były Niemcy, co znów potwierdza wniosek, że rynek ten był traktowany przez przedsiębiorców z województwa łódzkiego jako platforma do dalszego eksportu.

\section{Podsumowanie}

Przeprowadzone badanie pokazuje, że przedsiębiorstwa z województwa łódzkiego coraz chętniej angażują się w procesy internacjonalizacji, ale jednak nie jest to jeszcze zjawisko masowe. Pomimo tego można zauważyć jednak pewną sekwencyjność postępowania. W badanym okresie dominowały inwestycje nastawione na zwiększenie sprzedaży na rynki krajów goszczących (tj. inwesty- 
cje wspierające handel) podejmowane przede wszystkim w zbliżonych kulturowo krajach ościennych. Pionowa integracja procesu produkcji (szczególnie eksport wyrobów z jednostek zagranicznych do spółki matki), charakterystyczna dla doświadczonych inwestorów mających większy bagaż doświadczeń z działania na rynkach międzynarodowych, występowała w niewielkim zakresie, choć jej pojawienie się świadczy o systematycznym zdobywaniu doświadczeń i proaktywnym wykorzystywaniu okazji, jakie stwarza rynek międzynarodowy. Biorąc powyższe pod uwagę, można zauważyć pewne podobieństwo ścieżki rozwoju BIZ podejmowanych przez przedsiębiorstwa $\mathrm{z}$ województwa łódzkiego i modelu uppsalskiego.

\section{Literatura}

Bridgewater S., The Internationalisation Process and Types of Firms, w: International Business. Theories, Policies and Practices, ed. M. Tayeb, Pearson Education, Harlow 2000.

Brouthers K.D., Brouthers L.E., Acquisition or greenfield startup? Institutional, cultural and transaction cost influences, „Strategic Management Journal” 2000, vol. 21(1).

Calof J., Beamish P.W., Adapting to foreign markets: explaining internationalization, „International Business Review” 1995, vol. 4(2).

Cavusgil S.T., Knight G., Born Global Firms: A New International Enterprise, Business Expert Press, New York 2009.

Dikova D., Performance of foreign subsidiaries: Does psychic distance matter?, „International Business Review" 2009, vol. 18(1).

Evans J., Mavondo F.T., Psychic Distance and Organizational Performance: An Empirical Examination of International Retailing Operations, ,Journal of International Business Studies" 2002, vol. 33(3).

Fillis I., Small firm internationalisation: an investigative survey and future research directions, „Management Decision” 2001, vol. 39(9).

Fonfara K., Łuczak M., Przeglad podstawowych modeli internacjonalizacji firmy aspekty behawioralne, w: Zachowanie przedsiębiorstwa w procesie internacjonalizacji. Podejście sieciowe, red. K. Fonfara, PWE, Warszawa 2009.

Forsgren M., The Concept of Learning in the Uppsala internationalization process model: a critical review, „International Business Review” 2002, vol. 11(3).

Hashai N., Almor T., Gradually internationalizing 'born global' firms: an oxymoron?, „International Business Review” 2004, vol. 13(4).

Hollensen S., Global Marketing, a decision-oriented approach, Pearson Education Limited, Harlow, Essex 2004. 
Johanson J., Mattsson L.-G., Internationalization in industrial systems - a network approach, strategies in global competition, w: The Internationalization of the Firm: A Reader, ed. P.N. Buckley, P.J. Ghauri, Academic Press, London 1993.

Johanson J., Vahlne J.E., The internationalization process of the firm-A model of knowledge development and increasing market commitments, ,Journal of International Business Studies" 1977, vol. 8(1).

Johanson J., Vahlne J.-E., The Uppsala internationalization process model revisited: From liability of foreignness to liability of outsidership, „,Journal of International Business Studies" 2009, vol. 40(9).

Johanson J., Wiedersheim-Paul F., The Internationalization of the Firm - Four Swedish Cases, „The Journal of Management Studies” 1975, vol. 12(3).

Kłysik-Uryszek A., Kuna-Marszałek A., Psychic and geographic distance in the process of firm internationalization. Example of companies from Poland and Lodz region, „Business and Economic Horizons 2014, vol. 10(1).

Kogut B., Singh H., The Effect of National Culture on the Choice of Entry Mode, „Journal of International Business Studies" 1988, vol. 19(3).

Möller K., Rajala A., Rise of strategic nets - New modes of value creation, „Industrial Marketing Management" 2007, vol. 36.

Ng S.I., Zain M., The Impacts of Network Relationships on SMEs' Internationalization Process, „Thunderbird International Business Review”2006, vol. 48(2).

Przybylska K., Znaczenie dystansu psychicznego $w$ procesie internacjonalizacji polskich przedsiębiorstw, w: Przedsiębiorczość jako niewykorzystane źródło sukcesu polskiej gospodarki, red. E. Okoń-Horodyńska, PTE, Warszawa 2009.

Reid S.. Firm Internationalization, Transaction Costs And Strategic Choice, „International Marketing Review” 1983, vol. 1(2).

Sharma D.D., Blomstermo A., The internationalization process of born globals: a network view, „International Business Review” 2003, vol. 12(6).

Vahlne J.-E., Johanson J., New technology, new business environments and new internationalization processes?, w: Critical perspectives on internationalization, ed. V. Havila, M. Forsgren, H. Håkansson, Pergamon, London 2002.

\title{
EXPERIENCE OF INTERNATIONALIZATION PROCESS OF THE ENTERPRISES FROM LODZ REGION - AN ATTEMPT TO VERIFY UPPSALA MODEL
}

\begin{abstract}
The aim of the article is to present the process of internationalization of enterprises of the Lodz voivodeship in the context of Uppsala model of internationalization. The research results confirm the thesis that companies from the Lodz region, as well as an average all
\end{abstract}


Polish companies (excluding financial sector) proceed expansion path in accordance with the uppsala model. Due to relatively little experience in the active phases of internationalization, most investors have chosen those FDI forms, which allow them to increase sales (which is de facto export support strategy). As for the geographical breakdown of OFDI, the most popular directions of expansion are neighboring countries, with little psychic distance.

Translated by Agnieszka Kłysik-Uryszek, Anetta Kuna-Marszałek

Keywords: Uppsala model, Polish OFDI

JEL codes: F21, F23 
